\title{
Impacts of Sugarcane Farmland Expansion towards Food Security among Sugarcane-farming Households in Khon Kaen Province, Thailand
}

\author{
Itch Intarapoom *, Orawan Srisompun, Naris Sinsiri \\ Department of Agriculture Technology Mahasarakam University, Thailand \\ *Corresponding author email: Itch_Agri_Ento36@hotmail.com
}

Received: 07 July 2018 / Revised: 22 July 2018 / Accepted: 26 July 2018 / Published: 28 July 2018

\begin{abstract}
This study aimed to examine the impacts of sugarcane farmland expansion towards food security among the sugarcane-farming households in Khon Kaen Province, Thailand. A quantitative methodological approach was implemented in the study. The population of the study consisted of 3,332 sugarcane-farming households in Khon Kaen Province, who were associated with the Association of Sugarcane Farmers in the central-northeastern region during the production year of 2012/13. An interview schedule was implemented for data collection in order to collect data from the 357 sample households. Data was analyzed by the proportion of households who cultivated both sugarcane and rice. Four groups of sugarcane farming households were identified, including households where the proportion between sugarcane and rice plantation was 100:0, 75:25, 50:50, and 25:75. The research results indicated that the impact of expanding the cultivated area on the food security of farming households in Khon Kaen province could be seen at different levels, depending on the proportion of the area for cultivation of sugarcane to rice. The sugarcane-farming households with the proportion between sugarcane and rice plantation of 25:75 had the highest food security $(\bar{x}=3.54)$ and the sugarcane-farming households with the proportion between sugarcane and rice plantation of 100:0 had the lowest food security $(\bar{x}=3.05$ ). The study results suggested that the relevant agencies should support adequate food production in order to meet consumption requirements within the households. Promoting agricultural areas and resource management in farmland are considered to be necessary to enhance the food security of sugarcane farmers.
\end{abstract}

Keywords: food security, sugarcane, food crop, energy crop, food stability.

\section{Introduction}

Khon Kaen Province is home to a large sugarcane planting area, the third largest in the Northeast of Thailand, due to its suitable geographical landscape consisting mostly of low laying farmland. Moreover, Khon Kaen has been considered as a hub of the sugar industry in the Central-northeast Region of Thailand, due to there being many sugar mills and bio-energy factories located in the province. In the production year of 2013/14, Khon Kaen Province had a sugarcane planting area of 95,348 hectare (ha), with a production volume of 6,739,889 tons and a yield average of 70.69 tons/ha (Office of the Cane and Sugar Board, 2015). The sugarcane plantations in Khon Kaen have been expanding continuously, and this crop has replaced rice plantation. Many rice farmers in the province have changed their crops and sugar production increased every year since production year 2010/11. Sugarcane farmland had been increased, replacing rice, because sugarcane produced a higher selling price than rice production with sugarcane yields of approximately 
15,000 Thai Baht (469 USD) per hectare (Kusolkum \& Sethanant, 2012), while rice yielded only 3,750 Thai Baht (117 USD) per hectare (Tonpanya, 2011). The higher return from sugarcane therefore became a major motivation for rice farmers to shift to sugarcane production. However, it appears that the shift to cultivating sugarcane resulted in a reduction in the rice plantation area, and this directly affected the food security of the farm households since rice remains the primary consumption product of farm households in Khon Kaen (Khon Kaen Provincial Agriculture Extension Office, 2012). The trend of the rice planting area in Khon Kaen Province has gradually decreased from 453,845 ha in 2011 to 402,926 ha in 2012 (Khon Kaen Provincial Agriculture Extension Office, 2012). Recent research has found risks or challenges of land use and climate change towards food security of farming households which might be a global challenge (Popp, Lakner, Harangi-Rákos, and Fári, 2014; Rutten, Dijk, Rooij, and Hilderink, 2014). The circumstances of this directly affected upon the food security of farmers in the northeastern region, especially the sugarcane farming households. Shortage of food is a problem that has occurred in various regions around the world, especially in developing countries. It is a problem that has become an issue gaining high levels of attention from the public, governments, and the private sector at both domestic and international level due to food being one of the four basic needs for life and as collateral for human security.

\subsection{Elements of Food Security}

According to the concept of the FAO (Food and Agricultural Organization, 2001), food security is acquired within the elements of 4-Dimensions. The meaning of food security, in each dimension, can be explained as follows:

- The Availability Dimension refers to having sufficient food for consumption at all levels, individual, household, and country, which may result from domestic production or by imports from other countries, as well as received donations.

- The Accessibility Dimension refers to the ability to find food for consumption, both physically by their own production within the household, or from donors, and to have access to purchase within the economy. There must be enough food available to buy and the people must have adequate incomes in order to purchase.

- The Utilization Dimension refers to the utilization of available food that provides correct nutrition with safety, covers a variety of the 5 food-groups, gives energy, and provides enough nutrients for healthy body growth, with no food waste from consumption.

- The Stability Dimension refers to all the above dimensions being stable, with no shortage in some months, seasons, or years, as well as the people having access to food at any time they require it.

\subsection{Energy Crops to Food Security}

In 2007, the Food and Agriculture Organization (FAO) warned that 37 countries, around the world, were faced with a food crisis and the price of grain was at a high level on the world market; the use of many grains had changed to the production of alternative energy. The energy crops became the key variable in the change in the proportion of the planting area of food crops. It is distressing; the future consequences that follow from this phenomenon will impact upon mankind (Raneses et al, 1998).

As an example, Thailand has an aim to become a leader in renewable energy within ASEAN. The production of energy from renewable energy crops in Thailand began to be clearly seen from around 2005.

From table 1, it can be considered that 3 crops; sugarcane, cassava, and palm oil have been regarded as the main energy crops from 2005 to 2014. It was found that, in 2014, the cultivated area had increased to a total of approximately 867,200 hectares (5.42 million Rai) or 34.0 percent when compared to 2005 . The market price of sugar cane, with the world sugar market offering higher prices, caused farmers to increase their sugar cane production, while the use of energy crops in line with the Government's renewable energy policy also had an impact. When considering rice plantations, it was found that they also increased, but not on the scale of the energy crops. The rice planting area was also increased due to the Government's price intervention policies. However, in the future, without government interference in the price, then it is likely that the Thai rice plantation area may be reduced. Therefore, Thailand must review the management of 
Intarapoom et al., Adv.J Social Sci.; Vol. 4 Issue 1, pp: 11-17, 2019

production of food plants and energy crops to be appropriate and effective, with food distribution able to meet consumption requirements, adequately. Because of the expectation of a tendency to use food plants as an alternative energy source to substitute for fuel in a period high fuel prices, and their increasing use as a raw material in the production of bio-energy, this may affect food security in the future.

This paper examined the impacts of sugarcane farmland expansion towards food security among the sugarcane farming households in Khon Kaen Province, Thailand. Its challenge was to explore the impacts of the cultivation shift from rice to sugarcane in terms of plantation area, and how this cultivation shift affected the sugarcane-farming households. The contribution of the study should be beneficial to farm households, and the relevant authorities at local level, in dealing with the issue of food security. As a consequence, the farmers can adjust their cultivation ratio between energy crop plantation and food crop plantation, to make sure that their cultivation does not affect the farm household's food security.

\section{Methodology}

Quantitative methodological approach was implemented in the study. the population of the study utilized sugarcane-farming households in Khon Kaen province who were registered as members of the Association of Sugarcane Farmers in the Central-northeast Region during the production year of 2012/13, totally 3,332 members. The sample consisted of a total of 357 sugarcane-farming households, calculated by Taro Yamane's formula (Yamane, 1967). The sample was selected by a multi-stage random sampling method. First, purposive sampli method was applied to select the villages that had a large number of sugarcanefarming households. The listed sugarcane-farming households were selected by simple random sampling in accordance with calculated proportions.

Interview schedule was used as the tool to collect data. Interview schedule contained four dimensions of food security including 1) Household Food Availability (HHFAV) which was measured by independent variables included overall land (ha), rice yield in the past year (kilogram), and the amount of household rice reserves in the form of calories (Mugeniesyah \& Kosuke, 2004. In Thongpradap et al, 2009). 2) Household Food Access (HHFA) which was measured by independent variables included overall household income of the past month (Thai Baht/Household/Month), total of household food expenditure in the month (Thai Baht/Household/Month), and the variety of types and kinds of foods consumed in the household (Swindale \& Bilinsky, 2006). 3) Household Food Utilization (HHFU) which was measured by independent variables included the energy received, protein received, sufficient energy levels for adults, and sufficient protein levels for adults (Thongpradap et al, 2009). 4) Household Food Stability (HHFST) which was measured by independent variables included the ability to access adequate food (Songsriroj, 2015), using natural resources (Chareesri, 2009), the farm system (Chareesri, 2009), and knowledge and data (Songsriroj, 2015). And 5) Household Food Security (HHFS) which was measured by the values of independent variables in all four dimensions that were combined to align the proportion of weighing in order to find out the important variable of each dimension, and then the value of the overall household food security was calculated by equation (Mugeniesyah \& Kosuke, 2004. In Thongpradap et al., 2009)

Data analysis were conducted by dividing the proportion of the sugarcane planting area and the rice plantation area into four proportionate groups which included sugarcane per rice plantation area of 100:0, 75:25, 50:50, and 25:75 respectively. Descriptive statistics and F-test were applied to test level of food security in various dimensions. In addition, the Scheffe' test was applied to analyze the pair difference of the mean score.

\section{Results and Discussion}

The researcher analyzed quantitative data by dividing the proportion of the sugarcane planting area and the rice plantation area into four proportionate groups which included sugarcane per rice plantation area of 
100:0, 75:25, 50:50, and 25:75 respectively. The impact of the expansion of the sugarcane cultivation area towards food security was presented in accordance with various dimensions of food security as table below.

Table 1: The average of food security of sugarcane farming households in Khon Kaen Province by the proportion area of sugarcane plantation

\begin{tabular}{|l|c|c|c|c|c|c|c|c|c|}
\hline \multirow{2}{*}{ Issues } & \multicolumn{2}{|c|}{ 100: 0 } & \multicolumn{2}{c|}{$\mathbf{7 5 :} 25$} & \multicolumn{2}{c|}{$\mathbf{5 0 : 5 0}$} & \multicolumn{2}{c|}{ 25: 75 } & \multirow{2}{*}{ F } \\
\cline { 2 - 10 } & Mean & S.D. & Mean & S.D. & Mean & S.D. & Mean & S.D. & \\
\hline HHFAV & $1.68^{\mathrm{b}}$ & 0.34 & $2.51^{\mathrm{a}}$ & 0.22 & $2.48^{\mathrm{a}}$ & 0.28 & $2.45^{\mathrm{a}}$ & 0.29 & $193.826^{* * *}$ \\
& & & & & & & & & \\
\hline HHFA & 1.48 & 0.22 & 1.51 & 0.21 & 1.53 & 0.20 & 1.53 & 0.21 & $0.448^{\mathrm{NS}}$ \\
\hline HHFU & 1.66 & 0.18 & 1.66 & 0.23 & 1.60 & 0.16 & 1.68 & 0.25 & $0.918^{\mathrm{NS}}$ \\
\hline HHFST & $0.98^{\mathrm{b}}$ & 0.33 & $1.11^{\mathrm{a}}$ & 0.29 & $1.09^{\mathrm{a}}$ & 0.31 & $1.14^{\mathrm{a}}$ & 0.27 & $5.530^{* * *}$ \\
\hline HHFS & $3.05^{\mathrm{b}}$ & 0.37 & $3.51^{\mathrm{a}}$ & 0.26 & $3.46^{\mathrm{a}}$ & 0.25 & $3.54^{\mathrm{a}}$ & 0.27 & $53.192^{* * *}$ \\
\hline
\end{tabular}

Remark *** Statistical different at level .001

The average that was followed by the same English letter, which stayed in the same line, was not different statistically; NS: No statistical difference

According to table 1, major findings of food security level were described by dimension of food security as follows.

1) Household Food Availability (HHFAV), it was found that the sugarcane-farming households with the proportion of sugarcane and rice plantation at 75:25 represented the highest food security $(\bar{x}=2.51)$ (table 1). This was probably because these households had larger areas of farmland than other groups. However, the sugarcane farming households with their full area planted with sugarcane, 100:0 had the lowest food security $(\bar{x}=1.68)$ because they had more unused land than the other groups, or they kept less rice within the household than other groups. These findings conflicted with Thongpradap's findings (2010) who found that most households with high food insecurity, up to 70.20 percent, was due to these households owning less than 1.92 ha of farmland. Moreover, in cultivation, the households might not use all their areas of farmland to plant food crops, and the households with rice farming had, on average, a low level of productivity. Furthermore, the quantity of rice reserved for household consumption, measured in calories, was found to be at a lower level when compared to the sugarcane farming households in Khon Kaen province.

2) Household Food Access (HHFA), it was found that the sugarcane farming households, with the proportion between sugarcane and rice plantation of 100:0, had the lowest food security in regard to food access $(\bar{x}=1.48)$ (table 1$)$. This was due to the variety of food supply for consumption likely being low. These findings supported Jan-on's work (2014) who stated that a lack of food and nutrition in the population of some areas of Thailand might reflect the situation of food accessibility for the people living in those areas, such as a lack of protein and energy resulting from the uneven distribution of meat to disadvantaged groups. Some of the problem may have been caused because the farming group with its proportion of sugarcane and rice plantation at 100:0 may have a minimal cash balance. This was because this group of farming households did not produce enough rice for themselves, so they needed to buy rice and other foods for household consumption. They had larger food expenses, while their income was insufficient, and this resulted in them having a minimal bank balance. The results corresponded to the balance of the farming household group that cultivated sugarcane in the ratio of 25:75, who had the highest amount of money remaining for their food expenses. This farming group produced sufficient rice for home consumption, and so they did not have to purchase more. In addition, the rice farms produced more varieties of foods other than rice. They had more options in the foods they selected to consume.

3) Household Food Utilization (HHFU), it was found that the sugarcane farming households, with the proportion of sugarcane and rice plantation a $25: 75$, had the highest level of food security on food 
Intarapoom et al., Adv.J Social Sci.; Vol. 4 Issue 1, pp: 11-17, 2019

utilization $(\bar{x}=1.68)$ (table 1). It was because this farming household group produced the most rice, meaning they had enough rice for their own consumption. They also received sufficient nutrition in the form of reserved energy and carbohydrates. Moreover, rice farmland contained a variety of food ingredients that could be used in cooking. These findings were different to the study of Thongpradap (2010) who found households in the Karaked sub district, Chian Yai District, Nakhon Sri-Thammarat, faced food insecurity in terms of food utilization. They received protein of only 18.81 grams/person/day, while the body, typically, needed protein at least 52 grams/person/day. The number of households receiving insufficient protein was as high as 97.10 percent. Many households focused on foods that produced high energy rather than those which contained nutrients. This was different to the sugarcane farming households in Khon Kaen province, who mostly had access to foods which contained a high level of energy, protein, and carbohydrates. Although sugarcane-farming households regularly had less choice in the foods they consumed, those foods contained sufficient protein, energy, and nutrients in accordance with the 5 essentials.

4) Household Food Stability (HHFST), it was found that the sugarcane farming households, with the proportion between sugarcane and rice plantation at 25:75, had greater food stability than other farming household groups $(\bar{x}=1.14)$. This was the opposite of the sugarcane-farming households, with the proportion between sugarcane and rice plantation of 100:0, who had lower food stability than other farming household groups $(\bar{x}=0.98)$. This was probably because the households could access enough food, at all times, with no risk of sudden crisis. Households appropriately utilized the natural resources around their rice farm areas, they had a good plan for food production for their household consumption throughout the year and for market needs. Moreover, the households were members of various agriculture associations which contributed benefits to them if they were facing a shortage of food. These findings were different from the study of Songsriroj (2015) who investigated food security and the ability to manage farmer households in the areas managed by the Agricultural Land Reform Office of Maha Sarakham Province. The results revealed that the lowest score in the dimension of food stability was among the different dimensions of food security. This was because food stability was about immunity, the farmers might face less risks associated with a crisis that might arise suddenly, such as economic or climate issues. Households that used natural resources in the community were not suitable for the recovery of natural resources or their household lacked an integrated, overall farm system, etc.

5) Household Food Security (HHFS), it was found that the sugarcane farming households, with the proportion between sugarcane and rice plantation of $25: 75$, had the highest food security level $(\bar{x}$ $=3.54$ ), and the sugarcane-farming households with the proportion between sugarcane and rice plantation of 100:0, were found to have the lowest level of food security $(\bar{x}=3.05)$ (Table 1$)$. It was concluded that the sugarcane farming households, who grew rice more than sugarcane, would have a higher level of food security. Farmers in Khon Kaen province mostly reserved rice, in rice storage, for consumption within their households (Khon Kaen Provincial Agricultural Extension Office, 2012). Even though sugarcane production provided a higher income to farmers, and that income was essential for food intake, it was not stable in the same way as rice or other food production for home consumption. For example, if in the future the economy became stagnant, demand from power plants decreased and prices fell, or sugarcane disease, insect infestations affected the sugarcane farm, the households would not have enough income for their expenses. This would affect the food security of the farming households, and eventually, the food security of the country.

Overall, the group of sugarcane farming households, with the proportion between sugarcane and rice plantation of 25:75, had higher food security than the other groups because they had income from sugarcane production, and they had rice for household consumption. In the case that their rice yield provided a surplus, they could sell it to increase their household income. However, it may be a concern that if the 
Impacts of Sugarcane Farmland Expansion towards Food Security .................. in Khon Kaen Province, Thailand

farmers increased the proportion of sugarcane plantation area to earn more income from sugar cane and then used this income to buy food for consumption, instead of the rice reserved for household consumption, there could be the possibility they would face food insecurity in the future. These findings supported Jan-on (2014) who said that the factors that affect food security in Thailand are the proportions between food crops and energy crops. Due to the energy crisis and the impact of oil prices on the world market increasing since 2007, this resulted in Thailand giving priority to the production of energy supply plants and the use of renewable energy. The Government enacted a policy of promoting the development of bio-fuels and biomass such as ethanol and biodiesel, which were produced from food crops, especially cassava, sugarcane, and palm oil.

\section{Conclusion}

The impact of expanding the cultivated area on the food security of farming households in Khon Kaen province can be seen at different levels, depending on the proportion of the area for cultivation of sugarcane to rice. The farming households with a proportion of 75:25 have the highest level of food security in terms of household food availability, and households with a proportion of 100:0 have the lowest food security level in this dimension. While the farming households with a proportion of 100:0 have the lowest food security level in terms of food access, and the farming households with a proportion 25:75 have the highest food security level in terms of food utilization. The farming households with a proportion 25:75 have the highest food security in terms of food stability. Conversely, farming households with a proportion 100:0 have the lowest food stability level. Regarding food security, farming households with a proportion 25:75 have the highest food security level, and the farming households with a proportion 100:00 have the lowest food security level. The overall conclusion presents sugarcane-farming households, with the proportion between sugarcane and rice plantation of 100:0, having a lower food security level than other groups in all dimensions except the food utilization dimension. The sugarcane farming households, with the proportion between sugarcane and rice plantation of 25:75, have the highest food security level in all dimensions except for food availability and food access. The findings confirm Gardi (2015) and Jan-On (2014) who indicated that agricultural land is taken by many drivers such as biofuel production and urbanization, and it results in negative effect to food security of the locals. Finally, further qualitative research is recommended to investigate in-depth impacts of sugarcane farmland expansion towards food security.

\section{Declarations}

\subsection{Acknowledgments}

I would like to thank The Central Isarn Sugarcane Growers Association for their kind support and their useful information and advice. I also thank the sugarcane farmers in Khon Kaen province that kindly provided useful information for this study.

\subsection{Study limitation}

None

\subsection{Informed Consent}

Consent has been taken from the participants.

\subsection{Funding Source}

None

\subsection{Competing Interests}

No potential conflict of interest exists. 
Intarapoom et al., Adv. J Social Sci.; Vol. 4 Issue 1, pp: 11-17, 2019

\section{How to Cite this Article:}

Intarapoom, I., Srisompun, O., \& Sinsiri, N. (2018). Impacts of Sugarcane Farmland Expansion towards Food Security among Sugarcane-farming Households in Khon Kaen Province, Thailand. Advanced Journal of Social Science,4(1), 11-17. doi: 10.21467/ajss.4.1.11-17

\section{References}

Chareesri, A. (2009). Food security indicators in participatory guarantee system for Thai sustainable rice farming. Bachelor Thesis. Van Hall Larenstein University. Wagenigen. The Netherland.

Food and Agricultural Organization. (2001). State of food insecurity in the world. $\quad$ Food and Agriculture Organization of the United Nations. Retrieved from http://www.fao.org/docrep/003/y1500e/y1500e00.htm.

Gardi, C., Panagos, P., Liedekerke, M., Bosco, C., and Brogniez, D. (2015). Land take and food security: assessment of land take on the agricultural production in Europe. Journal of Environmental Planning and Management. 58(5), 898-912. Retrieved from https://doi.org/10.1080/09640568.2014.899490.

Jan-On, N. (2014). The food security of the Thailand country. Group tasks, monitoring and appraisal of the Senate Office of the academic Senate. 2(4), 7. Retrieved from library.senate.go.th/document/Ext7091/7091777_0002.PDF. [in Thai]

Kusolkum, C. and Sethanant, K. (2012). A study of the costs and returns in the production of sugarcane to the factory of retail sugarcane farmers in the area of Bua Khao sub-district, Kuchinarai District, Kalasin Province. Conference Network Engineering for the year 2012. The Faculty of Engineering. Khon Kaen University. [in Thai]

Khon Kaen Provincial Agricultural Extension Office. (2012). Report the result of the amount of rice planting areas of Khon Kaen Province. Department of agriculture, Ministry of agriculture and cooperatives. Retrieved from http://www. khonkaen.doae.go.th/upload/photo/data/20151027105556iAZ8CRc0.pdf. [in Thai]

Mugniesyah, S. and Kosuke, M. (2004). Women's land contribution and its relation to household food security among peasant households case in an upland village in West Java. In Proceedings of The Final Seminar: JSPS - DGHE Core University Program. On February 28-29, 2008 at The University of Tokyo, Japan. 168-172.

Thongpradub, A., Nissapa, A., Prapruit, P., \& Borormhtanarat, S. (2009). A Study on Levels of Household Food Security in Karakate Subdistrict, Chian-Yai District, Nakhon Si Thammarat Province. Academic Conference the Agricultural System, Number $5^{\text {th }}$ : Renewable energy and food security for humanity. (5), 283-292. [in Thai]

Office of the Cane and Sugar Board. (2015). Sugarcane areas report. Information technology group. The cane and sugar industry. The Office of the cane and sugar industry policy. Office of the cane and sugar Board. Retrieved from http://www.

ocsb.go.th/upload/journal/fileupload/923-9193.pdf.

Popp J, Lakner Z, Harangi-Rákos M, Fári M. (2014). The effect of bioenergy expansion: food, energy, and environment. Renewable and Sustainable Energy Reviews, 32, 559-578. Retrieved from https://doi.org/10.1016/j.rser.2014.01.056.

Prachasan, S. (2009). The development of indicators for food security. Foundation for Sustainable Agriculture (Thailand). Retrieved from https://www.nationalhealth.or.th/sites/default/files/upload_files/dmdocs/2_FS_index_report.pdf.[in Thai]

Raneses, A., Hanson, K., \& Shapouri, H. (1998). Economic Impacts from Shifting Cropland Use from Food to Fuel. Biomass and Bioenergy, 15(6), 417-422. Retrieve from https://doi.org/10.1016/S0961-9534(98)00048-8.

Rutten, M., Dijk, M., Rooij, W., and Hilderink, H. (2014). Land Use Dynamics, Climate Change, and Food Security in Vietnam: A Globalto-local Modeling Approach. World Development, 59, 29-46. Retrieved from https://doi.org/10.1016/j. worlddev.2014.01.020.

Songsriroj, N. (2015). Food security and household management capacity of farmer under Agricultural Land Reform Office in Mahasarakham province. NIDA Development Journal, 55(1), 1-25. Retrieved from https://doi.org/10.14456/ndj.2015. 6. [in Thai].

Swindale, A. and Bilinsky, P. (2006). Household Dietary Diversity Score (HDDS) for measurement of Hhousehold food access: indicator guide. Retrieved from http://www.ifpri.org/divs/fcnd/dp/papers/fcndp140.pdf.

Thongpradub, A., Nissapa, A., Prapruit, P., \& Borormhtanarat, S. (2009). A Study on Levels of Household Food Security in Karakate Subdistrict, Chian-Yai District, Nakhon Si Thammarat Province. Academic Conference the Agricultural System, Number $5^{\text {th }}$ : Renewable energy and food security for humanity. 5, 283-292. [in Thai].

Tonpanya, S. (2011). Cost and Return on Investment from Rice Farms of Farms of Farmers at Moo 5, Hua Dong Sub-district, Muang District, Phichit. Independent Study Master of Business Administration. Faculty of Business Administration Rajamangala University of Technology Thanyaburi. [in Thai]

Publish your research article in AIJR journals-

$\checkmark$ Online Submission and Tracking

$\checkmark$ Peer-Reviewed

$\checkmark$ Rapid decision

$\checkmark$ Immediate Publication after acceptance

$\checkmark$ Articles freely available online

$\checkmark \quad$ Retain full copyright of your article.

Submit your article at journals.aijr.in
Publish your books with AIJR publisher-

$\checkmark \quad$ Publish with ISBN and DOI.

$\checkmark$ Publish Thesis/Dissertation as Monograph.

$\checkmark$ Publish Book Monograph.

$\checkmark$ Publish Edited Volume/ Book.

$\checkmark$ Publish Conference Proceedings

$\checkmark \quad$ Retain full copyright of your books.

Submit your manuscript at books.aijr.org 